\title{
Isolated Coxiella burnetii synthesizes DNA during acid activation in the absence of host cells
}

\author{
Shu-Yin Chen, ${ }^{1 *}$ Michael Vodkin, ${ }^{2} \dagger$ Herbert A. Thompson ${ }^{1,2}$ and Jim C. Williams ${ }^{2,3}$ \\ ${ }^{1}$ Department of Microbiology and Immunology, School of Medicine, Health Sciences Center, West Virginia University, \\ Morgantown, WV 26506, USA \\ ${ }^{2}$ US Army Medical Research Institute of Infectious Diseases, Bacteriology Division, Department of Intracellular \\ Pathogens, Fort Detrick, Frederick, MD 21701-5011, USA \\ ${ }^{3}$ Office of the Director of Intramural Research Programs, National Institute of Allergy and Infectious Diseases, NIH, \\ Bethesda, MD 20892, USA
}

(Received 30 August 1989; revised 4 October 1989; accepted 16 October 1989)

\begin{abstract}
Two populations of Coxiella burnetii were isolated from fibroblast tissue cultures and examined for their ability to synthesize DNA when incubated in a defined medium. Both the populations released by mechanical lysis of heavily infected host cells, as well as those recovered from the tissue culture medium, incorporated $\mathrm{H}_{3}{ }^{2} \mathrm{PO}_{4}$ into DNA.

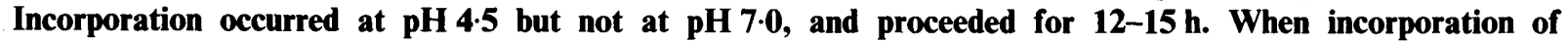
$\left[{ }^{3} \mathrm{H}\right.$ |thymidine was studied, only the organisms obtained by mechanical lysis of host cells were active. Those which had been released by natural means into the tissue culture medium, and then recovered for study, did not incorporate precursor thymidine but were extremely active in protein biosynthesis. In mechanically released organisms, thymidine incorporation was inhibited immediately by rifamycin $(40 \mu \mathrm{M})$ and hydroxyurea $(10 \mathrm{mM})$, but it was not affected by chloramphenicol $(310 \mu \mathrm{M})$ until $4 \mathrm{~h}$ after addition of the drug. Incorporation of $\mathrm{H}_{3}{ }^{32} \mathrm{PO}_{4}$ by both populations of organisms was also inhibited by rifamycin, chloramphenicol and hydroxyurea, but the time sequence of inhibition differed. Southern hybridization utilizing ${ }^{32} \mathrm{P}$-labelled DNA suggested that both populations synthesized authentic chromosomal DNA sequences, as well as QpH1 plasmid DNA, during acid activation of metabolism.
\end{abstract}

\section{Introduction}

Coxiella burnetii is an obligate intracellular bacterium and the agent of $\mathrm{Q}$ fever in humans. The organism is a moderate acidophile (Hackstadt, 1983; Hackstadt \& Williams, 1981 $a$ ), and parasitizes the phagolysosomal compartments of animal-host cells (Akporiaye et al., 1983; Burton et al., 1971, 1978; Hackstadt \& Williams, 1981 a). Although $C$. burnetii cannot be cultured in axenic media, both catabolic and anabolic reactions can be measured outside host cells in defined media, provided that the $\mathrm{pH}$ is in the range 4.0-5.5 (Hackstadt, 1983; Hackstadt \& Williams 1981 $a, b, c, 1983$; Hendrix \& Mallavia, 1984; Thompson et al., 1984; Zuerner \& Thompson, 1983). Success of the latter procedure, termed 'acid activation' of metabolism, is explained at least in part by energization of $C$. burnetii membranes

† Present address: Department of Pathobiology, College of Veterinary Medicine, University of Illinois, Urbana, IL 61801, USA. and of substrate transporters (proton symport: Hackstadt \& Williams, 1983; Hendrix \& Mallavia, 1984). Thus, when the organism is maintained in vitro at $\mathrm{pH} 4.5$, in the presence of an oxidizable substrate such as glutamate, the substrate is transported and metabolized, ATP is synthesized, and the energy charge approaches that presumably required for bacterial growth [Hackstadt \& Williams, $1981 b, 1983$; see Thompson (1988) for review]. Indeed, rapid isolation of $C$. burnetii from fibroblast cultures, followed by acid activation in vitro in media containing glucose, glutamate and the other amino acids, results in sustained protein biosynthesis by the organism (Zuerner \& Thompson, 1983). Under these conditions, approximately 24 polypeptide species are synthesized de novo by C. burnetii (Thompson et al., 1984; Zuerner \& Thompson, 1983); over 100 are seen if resolved on two-dimensional gels (R. L. Zuerner \& H. A. Thompson, unpublished). The translation measured during acid activation required de novo RNA synthesis. This suggests that $C$. burnetii mRNAs do not survive 
even a rapid isolation procedure (Zuerner \& Thompson, 1983). Transcripts synthesized during acid activation hybridize to both chromosomal and plasmid DNA (Frazier et al., 1985).

It is clear, then, that both gene transcription and translation occur in $C$. burnetii during artificial acid activation outside host cells. Since these biosyntheses are generally agreed to be the most energy-demanding reactions carried out by bacteria (Ingraham et al., 1983), it can be tentatively concluded that at least some of the cells in the $C$. burnetii populations studied are not energylimited. It is also apparent that ATP production and protein synthesis are not equivalent to growth. Growth of $C$. burnetii during acid activation has not been detected. At most, a $15-30 \%$ increase in C. burnetii protein biomass is observed over a $24 \mathrm{~h}$ incubation period (Zuerner \& Thompson, 1983). Our current concept of the $C$. burnetii cell under these conditions is that of an organism locked into a physiological maintenance state: few if any cells divide, and most cells probably do not traverse a significant portion of the cell cycle. Previous reports showed that acid activated organisms could incorporate nucleic acid precursors, including thymidine (Hackstadt \& Williams, $1981 c$ ). In an attempt to further elucidate the nature of the clamp on cell division in $C$. burnetii outside the host, DNA synthesis in the organism was investigated.

Two populations of $C$. burnetii can be harvested from persistently infected BHK-21 fibroblasts grown in monolayer culture (Zuerner \& Thompson, 1983). One population arises by either natural lytic events of heavily infected hosts or by exocytosis from infected cells. Organisms are allowed to accumulate in the medium over a $12-24 \mathrm{~h}$ period and then are harvested directly. The other population is obtained by mechanical (shear) lysis of infected host cells (Zuerner \& Thompson, 1983). As shown here, the two populations differ somewhat in their suitability for specific biochemical investigations. The present report gives evidence that only one $C$. burnetii population incorporates $\left[{ }^{3} \mathrm{H}\right]$ thymidine into chromosomal DNA during acid activation of metabolism. However, both populations incorporate $\mathrm{H}_{3}{ }^{32} \mathrm{PO}_{4}$ into chromosomal and plasmid DNA. The data suggest that DNA metabolism comprising either chromosomal replication or repair, or both, can occur in C. burnetii outside (parasitized) host cells.

\section{Methods}

Growth of fibroblasts. Baby hamster kidney cells (BHK-21) were obtained from the American Type Culture Collection (ATCC CL10). The fibroblasts were grown in monolayer cultures in Nunc $80 \mathrm{~cm}^{2}$ flasks with Dulbecco's Modified Eagle's medium (DME) containing $4 \mathrm{~g}$ glucose $1^{-1}$ and supplemented with $0.37 \%$ sodium bicarbonate and
$10 \%(\mathrm{v} / \mathrm{v})$ heat-inactivated newborn calf serum (Gibco). Cells were adapted to growth in a $15 \%(\mathrm{v} / \mathrm{v}) \mathrm{CO}_{2}$ atmosphere at $37^{\circ} \mathrm{C}$ prior to infection.

Infection of fibroblasts and growth of $C$. burnetii. Nine Mile strain phase I clone 7 [CB9MIC7; 307 guinea pig passages, tissue-culturecloned, followed by three egg passages (Williams et al., 1981)], was suspended in phosphate-buffered saline (PBS; $50 \mathrm{~mm}$-potassium phosphate, $\mathrm{pH} 7 \cdot 4,0.9 \%, \mathrm{w} / \mathrm{v}, \mathrm{NaCl}$ ) containing $5 \mathrm{mM}$-glutamate and $250 \mathrm{~mm}$-sucrose. Approximately $1 \times 10^{8}$ organisms in $0.5 \mathrm{ml}$ were used to infect each $80 \mathrm{~cm}^{2}$ fibroblast monolayer. A second source of $C$. burnetii Nine Mile strain phase I (uncloned), obtained originally from Dr D. Paretsky (University of Kansas, USA), was also used in some of these experiments. All ensuing procedures used to establish persistent infections with either source of organism were done as described previously (Zuerner \& Thompson, 1983). Infected BHK fibroblasts were cultivated for approximately 2 weeks to establish persistent infections. Thereafter, cultures of infected fibroblasts could be carried continuously through 10-15 passages without addition of either $C$. burnetii or fibroblasts. C. burnetii organisms were counted as described previously (Silverman et al., 1979).

C. burnetii Nine Mile strain phase II clone 4 (CB9MIIC4) was cultured and isolated as described before (Vodkin et al., 1986).

Harvesting populations of $C$. burnetii. Six days prior to harvest, confluent cultures of infected BHK-21 fibroblasts were trypsinized, diluted $1: 3$ with medium and reseeded into new $80 \mathrm{~cm}^{2}$ flasks $(1: 3$ split). After $72 \mathrm{~h}$, the medium ( $12 \mathrm{ml} \mathrm{DME}$ with $10 \%$ serum) was changed on the newly confluent monolayers. After an additional $48 \mathrm{~h}$ (and $24 \mathrm{~h}$ prior to harvest of $C$. burnetii) the tissue culture medium was changed a second time. This timing, and the maintenance of a $15 \%$ $\mathrm{CO}_{2}$ atmosphere over cultures of infected fibroblasts, were important for obtaining consistently high yields of active organisms.

C. burnetii organisms released by natural events (either host cell lysis or exocytosis) were harvested directly from the tissue culture medium after the $24 \mathrm{~h}$ accumulation period and washed by centrifugation (Zuerner \& Thompson, 1983). Rinsed monolayers were then trypsinized, and mechanically lysed to release intracellular $C$. burnetii, which were then partially purified by differential centrifugation (Zuerner \& Thompson, 1983). Organisms, obtained either from the medium or from host cells, were finally suspended in ice-cold glycine/phosphate buffer (120 mM-glycine, $169 \mathrm{~mm}-\mathrm{KCl}, 16 \mathrm{~mm}-\mathrm{NaCl}, 250 \mathrm{~mm}$-sucrose, and $49 \mathrm{~mm}-\mathrm{K}_{2} \mathrm{H}_{2} \mathrm{PO}_{4}$ for $\mathrm{pH} 4.5$ or $49 \mathrm{~mm}-\mathrm{K}_{2} \mathrm{HPO}_{4}$ for $\mathrm{pH} 7 \cdot 0$ ) at a concentration of approximately $1-2 \times 10^{11}$ organisms $\mathrm{ml}^{-1}$.

Measurement of DNA synthesis in a defined medium. Suspensions of $C$. burnetii were added such that they represented one-tenth the final volume of acid activation incubation mixtures. The final concentrations of chemical components were $250 \mathrm{~mm}$-sucrose, $5 \mathrm{~mm}$-glucose, $5 \mathrm{~mm}$-glutamate, $77 \mathrm{~mm}$-glycine, $0.1 \mathrm{~mm}$ of the 18 other amino acids, $118 \mathrm{~mm}-\mathrm{KCl}, 11.9 \mathrm{~mm}-\mathrm{NaCl}, 20 \mathrm{~mm}-\mathrm{MgCl}_{2}, 17.4 \mathrm{~mm}-\mathrm{KH}_{2} \mathrm{PO}_{4}(\mathrm{pH}$ $4.5)$ or $17.4 \mathrm{mM}-\mathrm{K}_{2} \mathrm{HPO}_{4}(\mathrm{pH} 7.0)$ and $0.6 \mathrm{~mm}$-thymidine, containing $100 \mu \mathrm{Ci}(3.67 \mathrm{MBq})\left[\right.$ methyl $\left.^{-3} \mathrm{H}\right]$ thymidine (Amersham or ICN) per $\mathrm{ml}^{-1}$ of incubation mixture. The final specific radioactivity of $\left[{ }^{3} \mathrm{H}\right]$ thymidine was $166 \mathrm{Ci} \mathrm{mol}^{-1}\left(6 \cdot 14 \mathrm{TBq} \mathrm{mol}^{-1}\right)$. Reactants were incubated with moderate shaking at $37^{\circ} \mathrm{C}$ under an atmosphere of air. Samples $(50$ or $100 \mu \mathrm{l})$ were withdrawn at the times indicated and applied to Whatman no. 3 filter paper discs. The radioactivity incorporated into nucleic acids precipitated with $10 \%(\mathrm{w} / \mathrm{v})$ TCA was determined by standard liquid scintillation procedures. The efficiency of counting was approximately $25 \%$. Results of representative experiments expressed as c.p.m. per sample are shown. Repeat experiments resulted in less than $\pm 15 \%$ error from those shown in Figs. 1-3.

The chemical homogeneity of $\left[\right.$ methyl $\left.{ }^{3} \mathrm{H}\right]$ thymidine used was verified by paper chromatography (Gasparic \& Characek, 1978) 
Extraction of C. burnetii DNA. To extract DNA probes for hybridization procedures, $1-2 \times 10^{11}$ organisms were first labelled by incubation with $1-2 \mathrm{mCi}(37-64 \mathrm{MBq}) \mathrm{H}_{3}{ }^{32} \mathrm{PO}_{4}$ under conditions as described for acid activation of organisms (above), except that the phosphate content of the incubation media was decreased to one-tenth that used for ${ }^{3} \mathrm{H}$-labelling. After incubation for $12 \mathrm{~h}, C$. burnetii organisms were pelleted by centrifugation at 30000 r.p.m. in a Spinco 40 rotor (Beckman), and DNA was extracted by an alkaline phenol method described previously (Vodkin et al., 1986). DNA was dissolved in $10 \mathrm{mM}-\mathrm{Tris} / \mathrm{HCl}(\mathrm{pH} 8 \cdot 0)$ containing $1 \mathrm{~mm}-\mathrm{Na}_{2}$ EDTA and stored at $4{ }^{\circ} \mathrm{C}$ until used.

Blot hybridizations. Chromosomal DNAs from phase I organisms (CB9MIC7) and from phase II organisms (CB9MIIC4) were obtained by alkaline phenol extraction (Vodkin et al., 1986). The entire DNA sequence found in plasmid $\mathrm{QpH} 1$ (obtained from CB9MIC7 and designated pCB9MIC7) was cloned in the cosmid pHC79 to yield pQpH201, while a plasmid found in CBKAVI, a C. burnetii heart valve strain, was also cloned completely into pHC79 to yield pQAVI02 (M. H. Vodkin \& J. C. Williams, unpublished). The procedures used to construct these recombinants were similar to those described for making a $C$. burnetii genomic library in the cosmid vector pHC79, as reported previously (Vodkin \& Williams, 1986). Chromosomal DNAs were restricted with HaeIII, whereas plasmid DNAs were restricted with EcoRI. Restriction digestions were done according to the specifications of the supplier (BRL). Electrophoresis was done in $0.9 \%$ agarose at $60 \mathrm{~V}$ for $2.5 \mathrm{~h}$. DNA blotting was done by the procedure of Southern (1975). DNA probes used were ${ }^{32} \mathrm{P}$-labelled DNA obtained by alkaline phenol extraction of DNA from mechanically released and naturally released $C$. burnetii after their acid activation in the presence of $\mathrm{H}_{3}{ }^{32} \mathrm{PO}_{4}$ (see above).

\section{Results}

\section{Thymidine incorporation by mechanically derived \\ C. burnetti}

C. burnetii organisms extracted from the intracellular compartments of infected host fibroblasts (by mechanical shear lysis) actively incorporated $\left[{ }^{3} \mathrm{H}\right]$ thymidine into the TCA-precipitable fraction when incubated in the defined medium at $\mathrm{pH} 4.5$. This incorporation of $\left[{ }^{3} \mathrm{H}\right]$ thymidine typically proceeded for $12-15 \mathrm{~h}$ before cessation and did not occur at $\mathrm{pH} 7.0$ (Fig. 1). The naturally released cells were not active in $\left[{ }^{3} \mathrm{H}\right]$ thymidine incorporation under the conditions tested (Fig. 1). Potential inhibitory effects of the naturally released cells, or of some inhibitor in that preparation of cells, was investigated by combining the two cell types. The presence of the naturally released cells had little effect, if any, on thymidine incorporation by mechanically released cells (Fig. 1). The naturally released $C$. burnetii did, however, incorporate $\left[{ }^{3} \mathrm{H}\right]$ leucine into protein (Fig. 2). Hence, the naturally released organisms used were biosynthetically active (Zuerner \& Thompson, 1983) but were unable to incorporate $\left[{ }^{3} \mathrm{H}\right]$ thymidine into DNA.

The isolation procedure used to obtain mechanically released organisms from the fibroblast host cells did not result in pure organisms free of host material (Zuerner \&

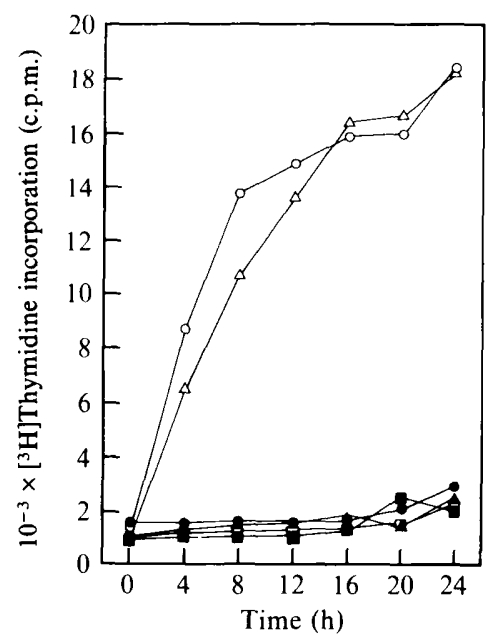

Fig. 1. Time-course of $\left[\right.$ methyl $\left.{ }^{3} \mathrm{H}\right]$ thymidine incorporation by $C$. burnetii during acid activation. Organisms were propagated and prepared for host-cell-free incubations as described in Methods. Incubations were done at $37^{\circ} \mathrm{C}$ in $1 \mathrm{ml}$ vols, from which $50 \mu 1$ samples were withdrawn at the indicated times; each sample contained approximately $5.5 \times 10^{8}$ organisms. One pmol of $\left[{ }^{3} \mathrm{H}\right]$ thymidine was equivalent to 92 c.p.m. Incorporation by mechanically released organisms $(O, \odot)$, by naturally released organisms $(\square, \square)$, and by mixtures of the two cell types $(\triangle, \Delta)$ was measured at $\mathrm{pH} 4.5$ (open symbols) and at $\mathrm{pH} 7.0$ (filled symbols).

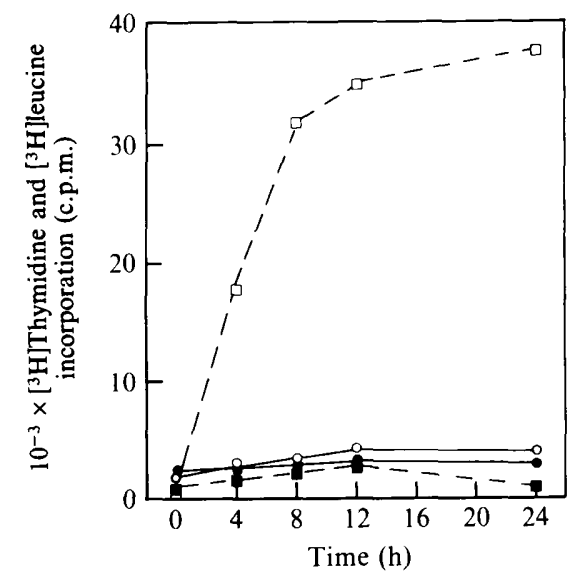

Fig. 2. Incorporation of $\mathrm{L}-\left(4,5-{ }^{3} \mathrm{H}\right)$ leucine by naturally released $C$. burnetii. Organisms (CB9MIC7), propagated as described in Methods, were suspended evenly in $\mathrm{pH} 4.5$ buffer and the suspension added to an incubation mixture without isotope. The mixed suspension of cells was then divided into two equal portions, one of which received [methyl$\left.{ }^{3} \mathrm{H}\right]$ thymidine $\left[0.6 \mathrm{mM} ; 166 \mathrm{Ci} \mathrm{mol}^{-1}\left(6.14 \mathrm{TBq} \mathrm{mol}^{-1}\right)\right]$ and the other received $\mathrm{L}-\left(4,5,{ }^{3} \mathrm{H}\right)$ leucine $\left[0.1 \mathrm{~mm} ; 992 \mathrm{Ci} \mathrm{mol}^{-1}\left(36.7 \mathrm{TBq} \mathrm{mol}^{-1}\right)\right]$. Incubation was done under standard conditions. Samples $(50 \mu \mathrm{l}$, each containing $7 \times 10^{8}$ organisms) were withdrawn at the indicated times and assayed for incorporated radioactivity, by either the hot-TCA (leucine) or cold-acid (thymidine) extraction technique. One pmol of $\left[{ }^{3} \mathrm{H}\right]$ leucine was equivalent to 545 c.p.m. --- , Leucine incorporation; - , thymidine incorporation. Incubations at $\mathrm{pH} 4.5$ are represented by open symbols; identically prepared suspensions incubated at $\mathrm{pH} 7.0$ are indicated by filled symbols. 
Table 1. $\left[{ }^{3} \mathrm{H}\right]$ Thymidine incorporation by C. burnetii

Incorporation of $\left[{ }^{3} \mathrm{H}\right]$ thymidine by mechanically released $C$. burnetii and by a sham preparation of BHK-21 cells was determined during incubation in a defined medium (see Methods). Equivalent numbers of host BHK-21 cells were used for sham preparations and for the preparation of mechanically released $C$. burnetii organisms.

\begin{tabular}{|c|c|c|c|c|}
\hline \multirow{3}{*}{$\begin{array}{l}\text { Time } \\
\text { (h) }\end{array}$} & \multicolumn{4}{|c|}{ Relative $\left[{ }^{3} \mathrm{H}\right]$ thymidine incorporation (c.p.m.) } \\
\hline & \multicolumn{2}{|c|}{ Sham preparation } & \multicolumn{2}{|c|}{$\begin{array}{c}\text { C. burnetii } \\
\text { (Mechanically-released) }\end{array}$} \\
\hline & $\mathrm{pH} 7 \cdot 0$ & $\mathrm{pH} 4 \cdot 5$ & pH 7.0 & $\mathrm{pH} 4 \cdot 5$ \\
\hline 0 & 1073 & 683 & 1078 & 788 \\
\hline 12 & 1683 & 1594 & 1482 & 15963 \\
\hline
\end{tabular}

Thompson, 1983). Rather, the procedure was based upon the development of assay conditions for $C$. burnetii activity exclusive of host nuclear or mitochondrial DNA synthesis. To ascertain the contribution (if any) of contaminating host cell components to the total incorporation observed, sham preparations extracted from uninfected BHK-21 fibroblasts were compared with those obtained from infected cells (Table 1). Material obtained by applying identical extraction procedures to uninfected cells was also incubated and found to have only limited capability for $\left[{ }^{3} \mathrm{H}\right]$ thymidine incorporation at $\mathrm{pH}$ 4.5. Only a small increment of incorporation (above time-zero backgrounds) was observed in the sham preparations incubated at $\mathrm{pH} 7.0$; incorporation by $C$. burnetii (after extraction from an equal number of infected host cells) was ten times higher than in the sham preparations (Table 1). In other trials, purified and heatkilled $C$. burnetii organisms were added to uninfected fibroblasts and then re-isolated. These preparations also showed little or no activity (data not shown).

\section{Effects of inhibitors on DNA synthesis}

The incorporation of $\left[{ }^{3} \mathrm{H}\right]$ thymidine by mechanically released organisms was inhibited by hydroxyurea, a drug which affects the ribonucleotide reductase step of DNA precursor formation (Sinha \& Snustad, 1972). Other inhibitors conventionally used to inhibit bacterial DNA synthesis, such as nalidixic and oxolinic acids, could not be effectively used because of their insolubility at low $\mathrm{pH} .\left[{ }^{3} \mathrm{H}\right]$ thymidine incorporation was also sensitive to rifamycin, which inhibits bacterial RNA polymerase. The inclusion of rifamycin in incubation mixtures at $\mathrm{pH}$ 4.5 resulted in an early effect on thymidine incorporation, with little thymidine uptake observed after $2 \mathrm{~h}$ of incubation (Fig. 3). Inclusion of chloramphenicol in the

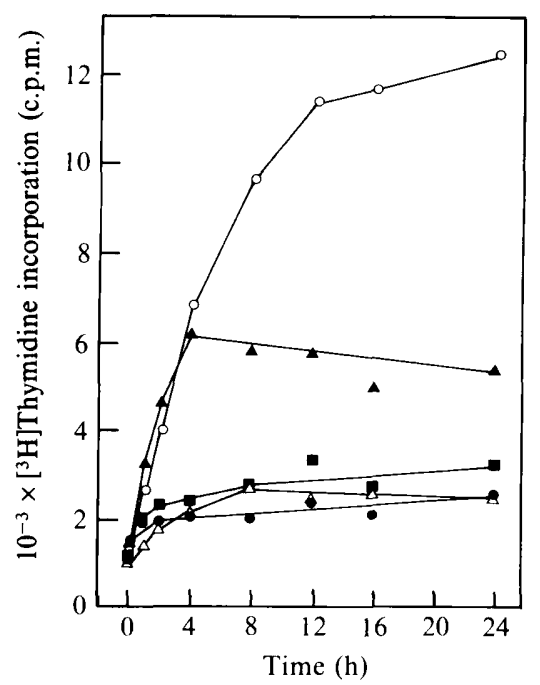

Fig. 3. Effects of inhibitors on $\left[\right.$ methyl $\left.{ }^{-3} \mathrm{H}\right]$ thymidine incorporation by mechanically released $C$. burnetii $\mathrm{CB} 9 \mathrm{MIC} 7$. All inhibitors were added at time-zero. Conditions of incubation, sampling and assay were otherwise as described in Fig. 1. Each sample contained $1 \times 10^{9} \mathrm{C}$. burnetii $O, \mathrm{pH} 4.5, /$ control without inhibitors; $\Delta, 0.31 \mathrm{mM}-$ chloramphenicol; $\triangle, 10$ mM-hydroxyurea; $\mathbf{\square}, 40 \mu \mathrm{M}$-rifamycin;, $\mathrm{pH}$ 7.0, without inhibitors.

incubation mixtures had no effect upon thymidine incorporation until the fourth hour of incubation, when thymidine incorporation ceased abruptly (Fig. 3). Chloramphenicol at this concentration $(0.3 \mathrm{mM})$ effectively inhibited $95-99 \%$ of leucine incorporation by mechanically released organisms (not shown: see Zuerner \& Thompson, 1983). Thus the initial $4 \mathrm{~h}$ period of DNA synthesis by $C$. burnetii during acid activation was dependent upon an active RNA polymerase, but not upon protein synthesis. Further experiments showed that mechanically released $C$. burnetii cells were similarly sensitive to inhibition by rifamycin regardless of when the drug was added (results from additions of rifamycin made at 2, 4, 6 and $8 \mathrm{~h}$ are not shown).

Previous observations (S. Y. Chen, H. A. Thompson \& R. L. Zuerner, unpublished; Zuerner \& Thompson, 1983) suggested that naturally released organisms did not readily incorporate uridine into RNA, even though these organisms required de novo RNA synthesis in order to simultaneously synthesize protein. Likewise, the present observations led to the suspicion that the inability of naturally released organisms to incorporate thymidine was indicative of a thymidine transport (or diffusion) deficiency in this cell population, rather than a lack of DNA synthesis. This hypothesis was tested by doing studies utilizing a different DNA precursor, $\mathrm{H}_{3}{ }^{32} \mathrm{PO}_{4}$. The results of these experiments are summarized in Table 2. Both mechanically released and naturally 
Table 2. $\mathrm{H}_{3}{ }^{32} \mathrm{PO}_{4}$ incorporation by C. burnetii

\begin{tabular}{|c|c|c|c|c|c|c|c|c|c|}
\hline \multirow[b]{3}{*}{$\mathrm{pH}$} & \multirow[b]{3}{*}{$\begin{array}{l}\text { Time (h) } \\
\text { Inhibitor }\end{array}$} & \multicolumn{8}{|c|}{$\mathrm{H}_{3}{ }^{32} \mathrm{PO}_{4}$ incorporation ${ }^{*}$} \\
\hline & & \multicolumn{4}{|c|}{ Mechanically released } & \multicolumn{4}{|c|}{ Naturally released } \\
\hline & & .0 & 2 & 4 & 12 & $\mathbf{0}$ & 2 & 4 & 12 \\
\hline $4 \cdot 5$ & None & $5 \cdot 9$ & $35 \cdot 3$ & $81 \cdot 0$ & 100 & $22 \cdot 9$ & $22 \cdot 6$ & $64 \cdot 9$ & 100 \\
\hline $4 \cdot 5$ & Rifamycin & $4 \cdot 6$ & $23 \cdot 1$ & $39 \cdot 1$ & $43 \cdot 0$ & $5 \cdot 7$ & $8 \cdot 0$ & $10 \cdot 5$ & $10 \cdot 9$ \\
\hline $4 \cdot 5$ & Chloramphenicol & $22 \cdot 9$ & $25 \cdot 6$ & $56 \cdot 7$ & $73 \cdot 8$ & $4 \cdot 6$ & $5 \cdot 8$ & $9 \cdot 5$ & $23 \cdot 4$ \\
\hline $4 \cdot 5$ & Hydroxyurea & $10 \cdot 1$ & 10.7 & $6 \cdot 8$ & $5 \cdot 8$ & $4 \cdot 6$ & $8 \cdot 6$ & 7.9 & $18 \cdot 2$ \\
\hline $7 \cdot 0$ & None & $7 \cdot 5$ & $8 \cdot 6$ & $7 \cdot 5$ & 5.9 & $5 \cdot 8$ & $13 \cdot 9$ & $9 \cdot 5$ & $37 \cdot 6$ \\
\hline
\end{tabular}

*Percentage of control without inhibitor at pH 4.5 after $12 \mathrm{~h}$.

released organisms incorporated ${ }^{32} \mathbf{P}$ into TCA-precipitable, alkali-stable material, and this uptake was dependent upon a low $\mathrm{pH}$. In both populations, hydroxyurea inhibited incorporation and activity was diminished in the presence of rifamycin, especially in the naturally released population. Incorporation by both populations was sensitive to chloramphenicol. Hence, a great deal of the ${ }^{32} \mathrm{P}$ incorporation by both populations depended upon both RNA and protein synthesis.

\section{Characteristics of labelling $\mathrm{DNA}$ with $\mathrm{H}_{3}{ }^{32} \mathrm{PO}_{4}$ and Southern blot hybridizations}

Inclusion of $\mathrm{H}_{3}{ }^{32} \mathrm{PO}_{4}$ in the media during acid activation resulted in a time-dependent, $\mathrm{pH}$-dependent incorporation of ${ }^{32} \mathrm{P}$ by both mechanically released and naturally released organisms (Table 2). The ${ }^{32} \mathrm{P}$-labelled DNA was extracted as described previously (Vodkin \& Williams, 1986). C. burnetii phase I and phase II chromosomal DNA was digested with HaeIII, and plasmid DNA was digested with EcoRI. The restricted DNA was then electrophoresed (Fig. 4). DNA fragments were transferred to nylon membranes (Hybond-N; Amersham), hybridized and autoradiographed. In Fig. 4B, DNA labelled during acid activation of mechanically released organisms was used as a hybridization probe. The probe hybridized to the chromosomal DNA of either phase I or phase II $C$. burnetii, such that a pattern resembling the ethidium-bromide-stained gels was evident (compare lanes 2 and 3 in Fig. 4B with those lanes in Fig. 4A). Very similar restriction patterns were observed on the autoradiograph of the HaeIII-digested ${ }^{32} \mathrm{P}$-labelled DNA also (not shown). The synthesized DNA also contained sequences that hybridized to fragments of the $C$. burnetii plasmid pCB9MIC7 (the QpH1 plasmid from C. burnetii 9MIC7 strain, lane 4) and to plasmid pCBKAVI (lane 5), although the latter hybridization was very weak. The digestion of pQpH201 with EcoRI yielded 11 pieces of DNA and only the third largest piece (about $7 \mathrm{~kb}$ ) contained vector DNA. The probe (Fig. 4B, lane 4) hybridized to three or more bands. Thus the low signal strength in this hybridization is likely to be due to the overall low amount of plasmid DNA in the probe DNA, and not to nonspecific hybridization to vector or other DNA. EcoRI-digested pQAV102 also yielded only one DNA fragment that contained vector DNA, and yet there were two faint hybridization regions (lane 5). The probe did not hybridize to EcoRI-restricted BHK-21 host-cell DNA (lane 6). Similarly, the ${ }^{32}$ P-labelled DNA from naturally released organisms likewise hybridized to the same restricted DNAs after Southern transfer (not shown).

\section{Discussion}

Incorporation of $\mathrm{H}_{3}{ }^{32} \mathrm{PO}_{4}$ into both populations of $C$. burnetii, and of $\left[{ }^{3} \mathrm{H}\right]$ thymidine into DNA by mechanically released $C$. burnetii only, occurred at $\mathrm{pH} 4.5$ but not at

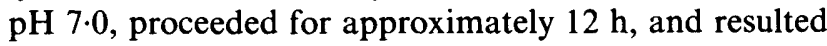
in labelling of both QpHI (pCB9MIC7) plasmid DNA and chromosomal DNA. Incorporated material was RNAase resistant and DNAase sensitive (not shown). The $\mathrm{pH}$ stimulation index, taken as the incorporation at $\mathrm{pH} 4.5$ divided by that at $\mathrm{pH} 7.0$, varied from 3 to 10 . The energization of the organism, or transport of the precursors, or both, is thus dependent upon a low-pH environment. It was also established that the presence of sucrose was important for DNA synthesis (data not shown). Without sucrose in the medium, DNA synthesis was delayed for several hours and the DNA that was synthesized was unstable. This latter observation suggests that osmotically fragile organisms, likely the LCV (large cell variant) forms (McCaul \& Williams, 1981), were involved in the DNA synthesis described here. 


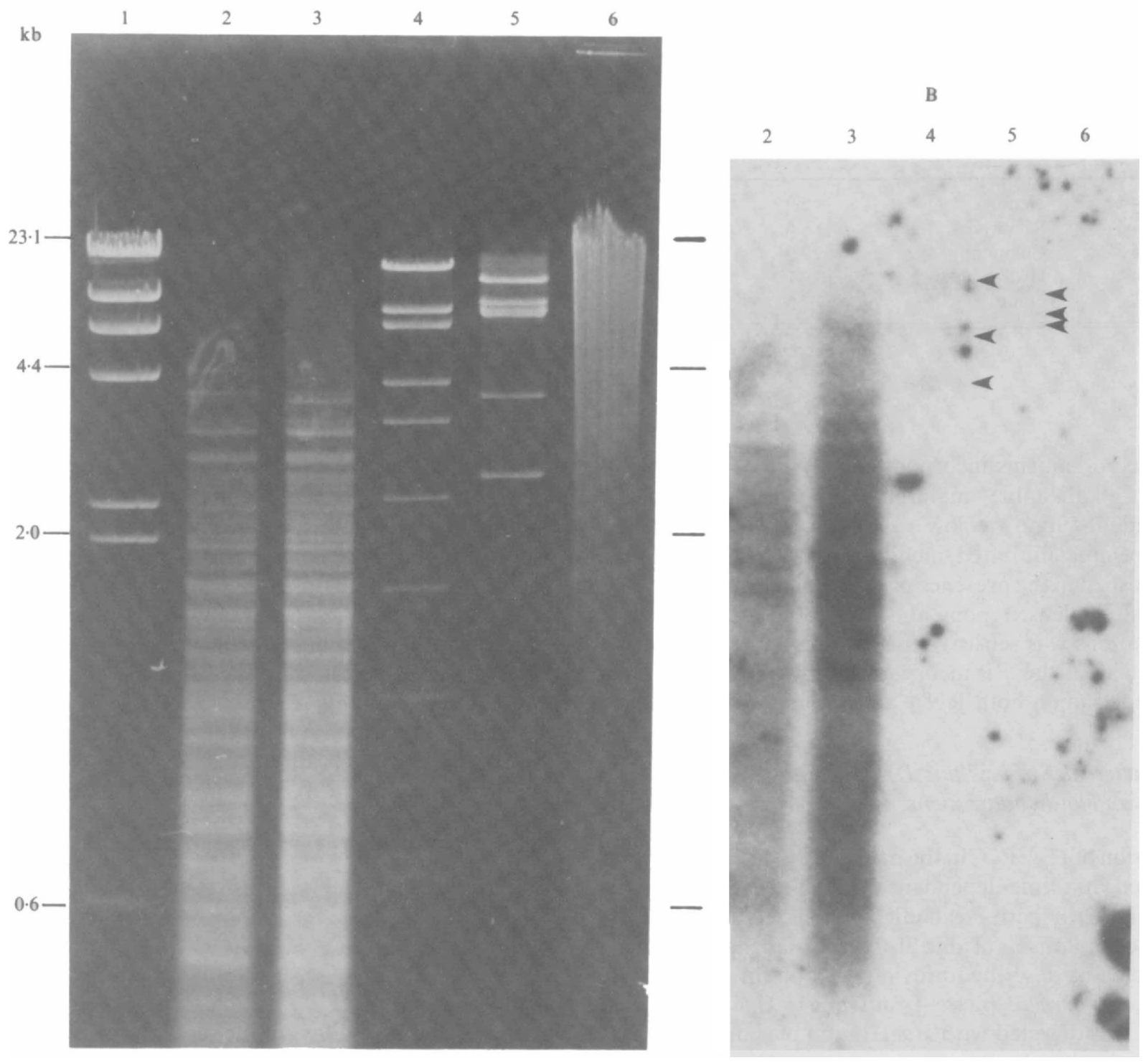

Fig. 4. Homology of DNA synthesized by mechanically released organisms during acid activation. A, ethidium bromide staining of $C$. burnetii DNAs. Digestions were done according to the specifications of enzyme suppliers. Lane 1, $\lambda$ DNA digested with HindIII; lane 2, CB9MIC7 DNA digested with HaeIII; lane 3, CB9MIIC4 DNA digested with HaeIII; lane 4, pQpH201 (cloned plasmid QpHI from strain CB9MIC7) digested with EcoRI; lane 5, pQAV102 (cloned plasmid from strain CBKAVI) digested with EcoRI; lane 6, uninfected fibroblast DNA digested with EcoRI. B, Southern blot hybridization to the agarose gel (panel A) using ${ }^{32}$ P-labelled DNA from mechanically released $C$. burnetii as probe. DNA was labelled by incubating mechanically released $C$. burnetii organisms with $\mathrm{H}_{3}{ }^{32} \mathrm{PO}_{4}$ at $\mathrm{pH} 4.5$ (acid activation) and was extracted by the alkaline phenol technique. Digested, electrophoresed DNAs were transferred to Hybond nylon filters and prehybridized. Hybridization was done using $1 \times 10^{5} \mathrm{c}$.p.m. of probe, in the presence of sheared salmon sperm DNA, for $20 \mathrm{~h}$ at $65^{\circ} \mathrm{C}$ under high stringency conditions. Film was exposed for $5 \mathrm{~d}$ prior development. Arrowheads indicate three visible hybridization bands in lane 4 and three barely perceptible bands in lane 5 .

$\left[{ }^{3} \mathrm{H}\right]$ Thymidine incorporation by mechanically released organisms occurred only when exogenously added thymidine concentrations were high $(300-600 \mu \mathrm{M})$. With high specific radioactivity thymidine $(1-2 \mu \mathrm{M})$, significant labelling was not observed (not shown). This suggests that higher concentrations of substrate are necessary in order that the organism may transport or use thymidine. During labelling with $\mathrm{H}_{3}{ }^{32} \mathrm{PO}_{4}$, it was also necessary to include $600 \mu \mathrm{M}$-thymidine. We do not know the reason for the inability of naturally released 
organisms to incorporate thymidine. Since they do synthesize DNA, it seems likely that either transport of the substrate or some early step in thymidine conversion to dTTP may be defective. We had noted before that this population is similarly poorly active in uridine incorporation (Zuerner \& Thompson, 1983). The explanation for these observations may be trivial. When mechanically released organisms were incubated for $24 \mathrm{~h}$ in the tissue culture medium ( $\mathrm{pH} \mathrm{7.4)}$ ) prior to acid activation, they lost most of their ability to incorporate thymidine (data not shown). We therefore believe that enzymes responsible for thymidine transport and incorporation in $C$. burnetii are unstable. It is known that other genera of obligate intracellular parasites lack some enzymes for nucleoside and nucleotide metabolism. For example, Chlamydia psittaci lacks thymidine kinase (Tribby \& Moulder, 1966) and Rickettsia typhi lacks both uridine kinase and thymidine kinase (Williams \& Peterson, 1976).

The genome size of $C$. burnetii Nine Mile strain phase I was found to be $1.04 \times 10^{9} \mathrm{Da}$ (Myers et al., 1980). The Nine Mile strain also possesses a plasmid, QpH1 (pCB9MIC7 from clone 7), that is $36 \mathrm{~kb}\left(2.4 \times 10^{7} \mathrm{Da}\right)$ in size and has a copy number of three (Mallavia et al., 1984; Samuel et al., 1983; Vodkin et al., 1986). A different plasmid, QpRS (pQKAVI), is found in $C$. burnetii isolates obtained from endocarditis patients (Samuel et al., 1985; Vodkin et al., 1986). In experiments not shown here, both Nine Mile sublines used replicated the QpHI plasmid during propagation in BHK-21 fibroblasts in the presence of aphidicolin. This was determined by restriction analysis of the DNA banding at a density of $1.62 \mathrm{~g} \mathrm{~cm}^{-3}$; such DNA is readily extractable from freshly isolated, mechanically released organisms. We therefore know that organisms used for DNA synthesis experiments in the present study contain plasmid DNA (results not shown). Thus, it was not surprising that DNA labelled with ${ }^{32} \mathrm{P}$ during acid activation hybridized to at least some QpH1 (pCBMIC7) plasmid fragments in Southern blotting procedures (Fig. 4). It is therefore likely that both naturally released and mechanically released $C$. burnetii synthesize plasmid and chromosomal DNA during these incubations outside host cells.

The DNA synthesis observed depended upon a rifamycin-sensitive step. Transcription is essential for initiation of DNA replication, but not repair, in many systems. It may function for (i) synthesis of an RNA primer, e.g. replication of ColE1-type plasmids (Minden \& Marians, 1985), or (ii) transcriptional activation of DNA replication, e.g. replication of $E$. coli chromosome and phage $\lambda$ DNA (Baker \& Kornberg, 1988; Furth \& Wickner, 1983). An alternative possibility, that transcription and translation of replication protein genes is necessary, is less satisfying because chloramphenicol did not inhibit $\left[{ }^{3} \mathrm{H}\right]$ thymidine incorporation until after $4 \mathrm{~h}$ of DNA synthesis (Fig. 3). Therefore the present studies indicate that processes with properties characteristic of DNA initiation were operative in $C$. burnetii as studied here, and suggest that this synthesis is not solely DNA repair. We have calculated that the quantity of DNA made during acid activation of mechanically released organisms represented an increase of $23 \%$ after a $12 \mathrm{~h}$ period. The calculation assumes no dilution of isotope by intracellular pools, and therefore should be conservative.

The long time-period during which DNA is made in $C$. burnetii in the presence of chloramphenicol $(4 \mathrm{~h})$ does not appear to be typical of other bacterial species under normal growth conditions. If chromosome replication is indeed occurring in the present case, and if re-initiation events only, and not elongation, require protein synthesis, then the results suggest that chromosome elongation during acid activation is extremely slow. On the other hand, this long-term refractility of $C$. burnetii DNA synthesis to chloramphenicol in the medium used here might suggest that we are studying the organism under poor nutrient conditions, such that an alternative pathway of DNA synthesis is being used. Significant DNA synthesis in $E$. coli can occur in the absence of protein synthesis, in mutants that lack RNAase $H$, producing constitutive Stable DNA Replication (cSDR). This alternative pathway in E. coli may operate under certain growth conditions in wild-type cells (Von Meyenberg et al., 1987). Whatever the mechanism, it is clear that $C$. burnetii isolated from their hosts do not immediately require synthesis of new proteins in order to synthesize DNA. However, RNA polymerase activity is required almost immediately upon acid activation.

We have shown, for the first time, that $C$. burnetii can synthesize DNA in the absence of host cells. However, the data do not permit us to ascertain why C. burnetii does not grow in the acidic, host-free medium. By definition, growth implies at least a doubling of both mass and numbers within a bacterial culture. It thus appears that C. burnetii replicates its DNA and yet does not finish a division cycle to form daughter cells. It is possible that this DNA synthesis observed during acid activation represents only partial chromosome replication. Alternatively, that portion of the organisms undergoing DNA synthesis in these studies may represent only a small subset of the population. Such a subset might be traversing one or more complete, but undetected, division cycles. These points require further investigation.

Most of this work was supported by a grant (PCM-7903282 to H.A. T.) from the National Science Foundation, and by the Biomedical Research Support Committee, WVU. We thank Rita May for 
secretarial assistance and acknowledge David Paretsky for suggesting experiments on DNA synthesis in Coxiella burnetii. We also thank Drs C. L. Harris, J. M. Novak and M. Vahey for their critical readings of this manuscript.

\section{References}

Akporiaye, E. T., Rowatt, J. D., Aragon, A. A. \& Baca, O. G. (1983). Lysosomal response of a murine macrophage-like cell line persistently infected with Coxiella burnetii. Infection and Immunity 40, $1155-1162$

BAKER, T. A. \& KoRNBERG, A. (1988). Transcriptional activation of initiation of replication from the $E$. coli chromosomal origin: an RNA-DNA hybrid near oriC. Cell 55, 113-123.

Burton, P. R., Kordova, N. \& Paretsky, D. (1971). Electron microscopic studies of the rickettsia Coxiella burnetii: entry, lysosomal response, and fate of rickettsial DNA in L-cells. Canadian Journal of Microbiology 17, 143-150.

Burton, P. R., Stueckemann, J., Welsh, R. M. \& Paretsky, D. (1978). Some ultrastructural effects of persistent infections by the rickettsia Coxiella burnetii in mouse L cells and green monkey kidney (Vero) cells. Infection and Immunity 21, 556-566.

Frazier, M. E., Mallavia, L. P. \& Samuel, J. E. (1985). Plasmid DNA isolated from phase 1 and phase 2 Coxiella burnetii. In Rickettsiae and Rickettsial Diseases, pp. 128-134. Edited by J. Kazar. Bratislava, Czechoslovakia: Publishing House of the Slovak Academy of Sciences.

FURTH, M. E. \& WICKNER, S. H. (1983). Lambda DNA replication. In Lambda II, pp. 145-173. Edited by R. W. Hendrix, J. W. Roberts, F. N. Stahl \& R. A. Weisberg. Cold Spring Harbor, NY: Cold Spring Harbor Laboratory.

GaSPARIC, J. \& CharaCEK, J. (1978). N-Heterocyclic compounds: purines, pyrimidines, and nucleosides. In Laboratory Handbook of Paper and Thin-layer Chromatography, p. 251. Edited by R. A. Chalmers. New York: Halsted Press.

HACKSTADT, T. (1983). Estimation of the cytoplasmic pH of Coxiella burnetii and effect of substrate oxidation on proton motive force. Journal of Bacteriology 154, 591-597.

HACKSTADT, T. \& Williams, J. C. (1981 $a$ ). Biochemical stratagem for obligate parasitism of eukaryotic cells by Coxiella burnetii. Proceedings of the National Academy of Sciences of the United States of America 78, 3240-3244.

HaCKSTADT, T. \& Williams, J. C. (1981 b). Stability of the adenosine $5^{\prime}$ triphosphate pool in Coxiella burnetii: influence of $\mathrm{pH}$ and substrate. Journal of Bacteriology 148, 419-425.

HaCKSTADT, T. \& Williams, J. C. $(1981 c)$. Incorporation of macromolecular precursors by Coxiella burnetii in an axenic medium. In Rickettsiae and Rickettsial Diseases, pp. 431-440. Edited by W. Burgdorfer \& R. L. Anacker. New York: Academic Press.

Hackstadt, T. \& Williams, J. C. (1983). pH Dependence of the Coxiella burnetii glutamate transport system. Journal of Bacteriology 154, 598-603.

Hendrix, L. \& Mallavia, L. P. (1984). Active transport of proline by Coxiella burnetii. Journal of General Microbiology 130, 2857-2863.

IngRaham, J. L., MaAløe, O. \& NiedhaRdt, F. C. (1983). Growth of the Bacterial Cell. Sunderland, Massachusetts: Sinauer Associates.
Mallavia, L. P., Samuel, J. E., Kahn, M. L., Thomashow, L. S. \& Frazier, M. E. (1984). Coxiella burnetii plasmid DNA. In Microbiology 1984, pp. 293-296. Edited by L. Lieve \& D. Schlessinger. Washington, DC: American Society for Microbiology.

McCaul, T. F. \& Williams, J. C. (1981). Developmental cycle of Coxiella burnetii: structure and morphogenesis of vegetative and sporogenic differentiation. Journal of Bacteriology 147, 1063-1076.

MINDEN, J. S. \& MARIANS, K. J. (1985). Replication of pBR322 DNA in vitro with purified proteins. Journal of Biological Chemistry $\mathbf{2 6 0}$, 9316-9325.

Myers, W. G., BaCa, O. G. \& Wisseman, C. L., JR (1980). Genome size of the rickettsia Coxiella burnetii. Journal of Bacteriology 144, 460461.

Samuel, J. E., Frazier, M. E., Kahn, M. L., Thomashow, L. S. \& Mallavia, L. P. (1983). Isolation and characterization of a plasmid from phase I Coxiella burnetii. Infection and Immunity 41, 488-493.

Samuel, J. E., Frazier, M. E. \& Mallavia, L. P. (1985). Correlation of plasmid type and disease caused by Coxiella burnetii. Infection and Immunity 49, 775-779.

Silverman, D. J., Fiset, P. \& Wisseman, C. L., JR (1979). Simple, differential staining technique for enumerating rickettsiae in yolk sac, tissue culture, extracts, or purified suspensions. Journal of Clinical Microbiology 9, 437-440.

SinHa, N. K. \& SNustad, D. P. (1972). Mechanism of inhibition of deoxyribonucleic acid synthesis in Escherichia coli by hydroxyurea. Journal of Bacteriology 112, 1321-1334.

SOUTHERN, E. M. (1975). Detection of specific sequences among DNA fragments separated by gel electrophoresis. Journal of Molecular Biology 98, 503-517.

Thompson, H. A. (1988). Relationship of the physiology and composition of Coxiella burnetii to the Coxiella-host cell interaction In Biology of Rickettsiae and Rickettsial Diseases, pp. 51-78. Edited by D. H. Walker. Boca Raton, Florida: CRC Press.

Thompson, H. A., Zuerner, R. L. \& Redd, T. (1984). Protein synthesis in Coxiella burnetii. In Microbiology 1984, pp. 288-292. Edited by L. Lieve \& D. Schlessinger. Washington, DC: American Society for Microbiology.

TribBy, I. I. E. \& Moulder, J. W. (1966). Availability of bases and nucleosides as precursors of nucleic acids in $\mathrm{L}$ cells and in the agent of meningopneumonitis. Journal of Bacteriology 91, 2362-2367.

VodKIN, M. H. \& Williams, J. C. (1986). Overlapping deletion in two spontaneous phase variants of Coxiella burnetii. Journal of General Microbiology 132, 2587-2594.

Vodkin, M. H., Williams, J. C. \& Stephenson, E. H. (1986). Genetic heterogeneity among isolates of Coxiella burnetii. Journal of General Microbiology 132, 455-463.

Von Meyenburg, K., Boye, E., Skarstad, K., Koppes, L. \& Kogoma T. (1987). Mode of initiation of constitutive stable DNA replication in RNAse H-defective mutants of Escherichia coli K-12. Journal of Bacteriology 169, 2650-2658.

Williams, J. C., Peacock, M. G. \& McCaul, T. F. (1981). Immunological and biological characterization of Coxiella burnetii, phase I and II, separated from host components. Infection and Immunity 32, 840-851.

Williams, J. C. \& Peterson, J. C. (1976). Enzymatic activities leading to pyrimidine nucleotide biosynthesis from cell-free extracts of Rickettsia typhi. Infection and Immunity 14, 439-448.

ZUERNER, R. L. \& THOMPSON, H. A. (1983). Protein synthesis by intact Coxiella burnetii cells. Journal of Bacteriology 156, 186-191. 